\title{
血管造影法による皮弁血行の研究
}

\section{中嶋 英雄（慶応大学・形成外科）}

形成外科, とりわけ再建外科の分野から画像診断の活

用について述べる。

形成外科は基本的に形態の再建を主たる目標とする分 野であるから組織欠損の，あるいは欠損となるであるう 組織の形態を直接的に，より正確に把握することは再建 計画をたてる上で極めて重要なことである。その意味か らも画像診断がより詳細な術前診断を可能にして来たこ とは，再建法を検討する上でより具体的な立案が可能と なり，再建外科にとっても利益は大きい。

とくに頭蓋顔面奇形や胸郭変形など骨を中心とした変 形疾患や，骨や骨浸潤性の腫瘍性疾患に扔いてはX線 CT は，再建計画に最も有力な情報を提供し，さらには 最近の 3 次元 CT の開発は病変の 3 次元的把握をより 直接的, 容易なむのにし今後が大いに期待される。私達 はシーメンス社のプログラムを用いてソマトム DR3 に よる 3 次元表示を現在改良中であり，また独自のプログ ラムも開発中である（図 1)。

頭突部領域に㧍ける再建外科と画像診断との直接的関 わりは皮弁血行に関与するものと思われる。皮弁の理論 的発展は皮膚血行の解明によるものであり, 現在皮膚血 行の概念は血行形態，血行動態の 2 面よりとらえられて いる。前者は皮膚血行を司る血管構築の解剖学的理解で あり, 演者はそれらに新しい見解を加え独自の皮弁分類 法を提呾している。後者は血管皮膚支配領域の状況下に おける動的変化を知ることであり，直接的には皮弁の生 着範囲を推定しうる点で臨床的に意味を持つ。

演者は Prostaglandin E 1 を用いた薬理学的血管造影 法を応用して，血管皮膚支配領域を測定し，ほぼ全身の 分布図を作製した（図 2 )。これは正常生体下における 各血管の皮膚支配領域を示し, Manchot らが屍体色素 注入法で表わした 分布図とはいくつかの 差異がみられ た。

またこれらの隣接する領域相互の dynamism を臨床 及び動物実験で明らかにすることで皮弁の拡大生着範囲 に方向性のあることを見い出した。この事実は拡大筋皮 弁, 拡大筋膜皮弁の理論的根拠となり新しい皮弁の開発 にっながってきている。

上慰動脈，下慰動脈各々に選択的にカテーテルを挿入 し Prostaglandin $\mathrm{E}_{1} 10 \mu \mathrm{g}$ を注人し発赤変化としてとら えられた血管皮膚支配領域を測定すると両者は境界線を もって接する。次に上繁動脈をバルーンカテーテルにて 血行途絶しつつ再び選択的に下层動脈の発赤範囲を測定

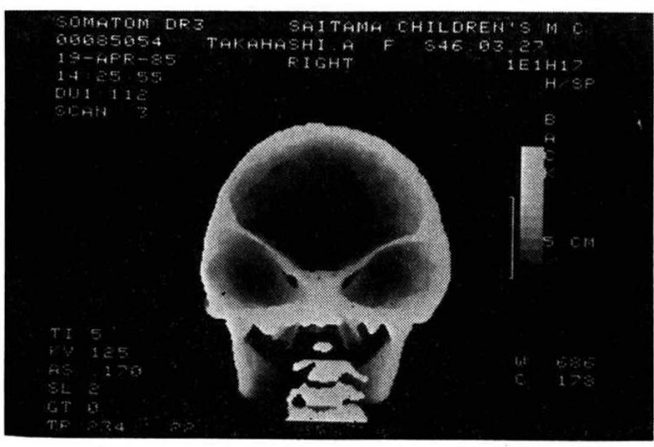

図 1 Crouzon 氏病の前・中頭蓋を後方より みた 3 次元表示像。

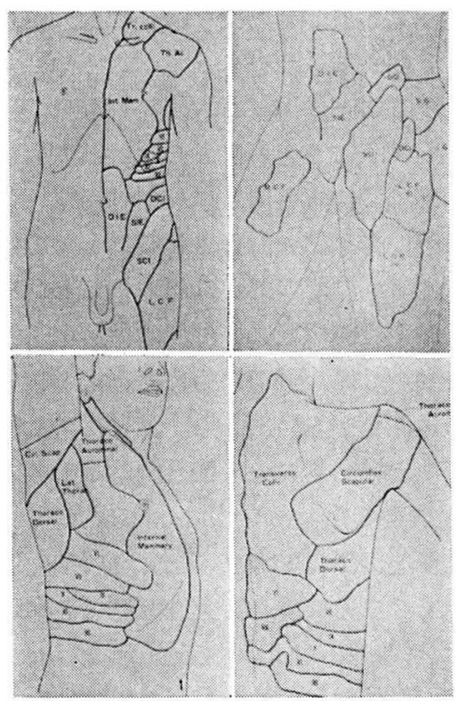

図 2 Prostaglandin $\mathrm{E}_{1}$ による 血管皮膚支配 分布図。

すると今度は，本来は上慰動脈の支配領域であったとこ ろまで拡大しているのがわかる（図 3 ）。この現象は周 辺領域との血行の支配関係はある種の圧のバランスであ り解剖学的な血管支配体系を基本としつつも，血行の動 的変化により血管皮膚支配領域は容易に変動することを 示唆する。実際に皮弁を挙上する時，血行動態の変化に よる生着範囲の拡大は fasciocutaneous plexus（筋膜血 管網）の形態により左右される為, 拡大生着範囲は周辺 に均一にのびるのではなく，ある種の方向性がみられる ことになる。

これら事実から演者は, 従来経験的に筋皮弁に可能と 


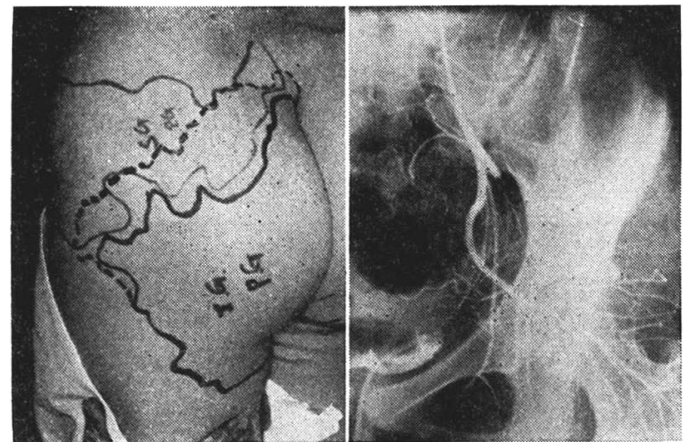

図 3 （左）下慰動脈の皮膚支配領域（実際） は上剧動脈を遮断することで上䌓動脈の 支配領域まで拡大する (断線)。(右) 上 慰動脈をバルーンカテーテルにて遮断し て下魂動脈の血行を確認する血管撮影。

された拡大生着範囲と理論的根拠をあたえるとともに， 拡大範囲が random pattern として一律化して説明しき れない各種拡大筋皮弁を開発した。拡大大臀筋皮弁では 腰部，ソケイ部へ筋膜皮弁を拡大附着させ巨大な trilobed flap とすることで熨部巨大組織欠損や, 多発裖瘡を 一期的に再建することを可能とした。拡大広背筋皮弁で は広背笳前部 $1 / 2$ に側腹あるいは肩甲骨内側へ長さ/幅比 4：1の笳膜皮弁を拡大附着させることで笳機能を損う ことなく頸部，前胸部の再建に用いることができた。

拡大筋皮弁の皮膚領域の血行理念は, 旧来の皮弁の血 行概念を一変させ，ついで筋膜皮弁を中心とした多くの 新しい皮弁の開発へと発展した。演者は，血行機序によ り筋膜皮弁を皮弁全体の中で位置づけるとともに新しい 12の flap を開発した（表 1)。これら皮弁は，また PGE， 薬理学的血管造影法にて本来の血管皮膚支配領域が確認 されることで, 皮弁生着の安全性と拡大皮弁の可能性が 高められた。代表的な flap を述べると lumbo glutal flap は, 第 4 腰動脈穿通枝を茎とし腸稜上をンケイ部か

\section{表 4 新しく開発した皮弁}

1. Infrascapular fasciocutaneous flap.

2. Paramedian chest fasciocutaneous flap.

3. Lumbogluteal fasciocutaneous flap.

4. Infraclavicular fasciocutaneous flap.

5. Cervicodorsal fasciocutaneous flap.

6. Lateral femoral fasciocutaneous flap.

7. Inner medial femoral fasciocutaneous flap.

8. Suprasacral fasciocutaneous flap.

9. Infrasacral fasciocutaneous flap.

10. Perineal fasciocutaneous flap.

11. Anterior tibial septocutaneous flap.

12. Posterior interosseous septocutaneous flap.

（中嶋 1982-1985）

ら大転子部まで挙上採取できる筋膜皮弁で，有茎で仙骨 部大転子部裖瘡の再建に，遊離皮弁としては脂肪の厚さ から乳房再建に適している。Infrascapular flap は第 6 助間動脈穿通枝を茎とする肩甲骨下の筋膜皮弁で皮下脂 肪がうすく遊離皮弁に適している。

再建外科にとって血管造影は単に皮弁の栄養血管の存 在を確認するだけでなく，血管のもつ本来の皮膚支配領 域を患者自身から直接的に明らかにすることができ，皮 弁設計の安全性を高めてきた。また血管皮膚支配領域の dynamism から皮膚血行に 新しい概念が導入され，皮 弁そのものが新しい分類整理を余儀なくされ同時に多く の新しい皮弁が開発されることになった。新しい画像は 単に臨床診断能を高めるだけにとどまるものではなく, より根元的なものを発見する機会を常に内包しているも のと考える。 